\title{
Decifrando hieróglifos: o capital mercantil no centro da América do Sul (1718-1750) ${ }^{1}$
}

\author{
Tiago Kramer de Oliveira ${ }^{2}$
}

\begin{abstract}
O valor não traz escrito na fronte o que ele é. Longe disso, o valor transforma cada trabalho num hieróglifo social. Mais tarde, os homens procuram decifrar o significado do hieróglifo, descobrir o segredo de sua própria criação social, pois a conversão dos objetos úteis em valores é, como a linguagem, um produto social dos homens (Karl Marx em O capital).
\end{abstract}

\section{Resumo}

Este artigo analisa características da reprodução econômica colonial em uma área de fronteira e de intensa exploração aurífera, buscando perceber como as diversas atividades econômicas expressavam manifestações do capital mercantil. Nosso recorte espacial compreende as minas do Cuiabá e as minas do Mato Grosso, territórios localizados no centro da América do Sul, e que na primeira metade do século XVIII integravam o termo da Vila Real do Senhor Bom Jesus do Cuiabá, submetidas administrativamente à capitania de São Paulo, no extremo oeste do Estado do Brasil.

Palavras-chave: Economia colonial; Capital mercantil; Capitania de São Paulo; Capitania de Mato Grosso; Século XVIII.

\section{Abstract \\ Deciphering hieroglyphs: the trade capital in the center of South America (1718-1750)}

This article examines characteristics of colonial economic reproduced in an area of intense gold exploration, seeking to rebuild links between the various economic activities and trade capital. The spatial area of our study covers the mines of Cuiaba and the mines of Mato Grosso, territories located in the heart of South America, and that in the first half of the eighteenth century were part of the Vila Real do Senhor Bom Jesus do Cuiabá, subject to administrative captaincy of São Paulo, in the extreme west of the State of Brazil.

Keywords: Colonial economy; Trade capital; Captaincy of São Paulo; Captaincy of Mato Grosso; Eighteenth century.

JEL N56, N96.

Historiadores consagrados por estudos em história econômica, como Vitorino de Magalhães Godinho, Frédéric Mauro e Pierre Vilar, destacaram o papel do ouro da América Portuguesa para a acumulação de capital na Europa, em

(1) Trabalho recebido em 5 de dezembro de 2009 e aprovado em 13 de outubro de 2010.

(2) Professor da Universidade Federal do Triângulo Mineiro (UFTM). Bolsista Capes (Coordenação de Aperfeiçoamento de Pessoal de Nível Superior), Uberaba, MG, Brasil. E-mail: kramerhis@gmail.com. Agradeço a orientação do professor Carlos Alberto Rosa na elaboração da primeira versão deste texto. Os resultados desta pesquisa integram nosso projeto de doutoramento orientado pelo professor José Jobson de Andrade Arruda no âmbito do programa de pós-graduação em História Econômica da Universidade de São Paulo. Agradeço ainda as sugestões e críticas dos pareceristas desta revista.

Economia e Sociedade, Campinas, v. 20, n. 3 (43), p. 661-690, dez. 2011. 
particular em Portugal e na Inglaterra. Segundo Godinho, a "Revolução Industrial (...) deve certamente muito ao ouro brasileiro" (Godinho, 1950, p. 87). Para Vilar, embora Portugal fosse o primeiro beneficiário das importações de ouro para a Europa, a Inglaterra, "pelo constante excedente de sua balança comercial com Portugal" conseguia "drenar" grande parte desse ouro (Vilar, 1980, p. 284). Mesmo que os autores pudessem exagerar no teor dessa "drenagem" e sua importância para a economia inglesa, não há dúvida de que o ouro português, extraído de sua maior possessão colonial, teve impactos na história econômica europeia (e inglesa) e na fixação do padrão-ouro no comércio internacional (Godinho, 1950, p. 87).

Neste artigo analisaremos alguns aspectos da economia reproduzida no centro da América do Sul, na primeira metade do século XVIII, local em que a partir de 1718 houve a sistemática exploração de ouro. Ali houve também a formação de uma diversidade de ambientes coloniais nas minas do Cuiabá: lavras, roças, sítios, engenhos, fazendas, povoados, arraiais e, em 1727, a fundação da Vila Real do Senhor Bom Jesus do Cuiabá, que marcou a consolidação da presença portuguesa. Na década de 30 do mesmo século ocorreu a expansão das conquistas em direção oeste, formando outra espacialidade ${ }^{3}$ : as minas do Mato Grosso. Ambas as minas, a do Cuiabá e a do Mato Grosso, integravam o termo da Vila Real e estavam submetidas ao governo da capitania de São Paulo até a fundação da capitania de Mato Grosso (1748) e da edificação da Vila Bela da Santíssima Trindade (1752), capital da nova capitania.

Todavia, o que queremos discutir não é a importância do ouro extraído no centro da América do Sul, nas minas do Cuiabá e nas minas do Mato Grosso para o quadro da história econômica e monetária europeia do século XVIII. Queremos chamar a atenção para outro problema, aparentemente de pouca importância, mas de implicações mais amplas do que aparenta: o que de fato continha no ouro que era enviado para a Europa e contribuía na retroalimentação do capital mercantil? A questão parece descabida, mas veremos que um "estranhamento" deste tipo pode contribuir para refletirmos sobre as articulações entre as diferentes atividades produtivas que caracterizam o capital mercantil. O ouro era resultado de um conjunto de relações que permanecem como um mistério que a história monetária não se preocupou em enunciar.

A ênfase de parte da produção histórica na importância da produção aurífera fez com que outras características econômicas e sociais fossem ignoradas ou colocadas em um plano que não corresponde à importância efetiva que tiveram. A fundação da Vila Real do Senhor Bom Jesus do Cuiabá em 1727, por exemplo, tem sido explicada como manobra fiscal, cujos únicos objetivos eram coibir os descaminhos do ouro e ampliar a arrecadação. Apesar de a preocupação fiscal ser

(3) Segundo Milton Santos, "a espacialidade seria um momento das relações sociais geografizadas, o momento da incidência da sociedade sobre um determinado arranjo espacial" (Santos, 1988, p. 26). 
verificável na documentação, ela não justifica, e muito menos explica, a fundação da Vila Real. "Neste sentido, o fisco ofusca" (Rosa, 2003, p. 37).

No ano de 1727, segundo Washington Luis (1938), o valor dos quintos cobrados em Cuiabá foi de 51.589 oitavas de ouro, ou 185,7 kg. Esse ouro jamais chegaria a Portugal, uma vez foi alvo de fraude e trocado por chumbo. Mas o valor apontado por Washington Luis não era referente apenas à parte do ouro extraído das minas, mas também dos demais "direitos" cobrados pela Coroa. Não há discriminação detalhada dos percentuais, mas segundo Nogueira Coelho, 16.722 oitavas, ou seja, pouco mais de $32 \%$ do total de ouro que deveria ser enviado foi fruto de cobrança dos direitos das entradas. Outros direitos, como os dízimos e maneios não são especificados, mas deveriam constar no total de ouro que seria enviado a Lisboa.

Se a troca, ou "metamorfose", , de ouro em chumbo provocou tensões, devassas, murmúrios, múltiplas interpretações, outra transmutação não mereceu a mesma atenção das autoridades metropolitanas e colonos (e muito menos dos historiadores): a "metamorfose" de milho, feijão, mandioca, carne, aguardente, tabaco, entre outras mercadorias, em ouro. O ouro extraído dessas atividades, de valor nem um pouco desprezível, era introduzido nas redes mercantis. No entanto, a mercadoria-ouro silencia as práticas sociais, as relações de intercâmbio, a divisão do trabalho que permitiram sua constituição como valor.

Para Marx, "para funcionar como dinheiro, tem o ouro que penetrar no mercado por algum ponto" e "esse ponto se encontra na sua fonte de produção, onde o ouro, como produto imediato do trabalho, se troca por outro produto do trabalho do mesmo valor", "a partir deste momento, passa a representar os preços realizados das mercadorias". Ainda segundo o autor, por meio dessa "metamorfose", "apaga a mercadoria qualquer vestígio de seu valor-de-uso natural e do trabalho útil particular que lhe deu origem, para se transformar na materialização uniforme e social de trabalho humano homogêneo". O autor acrescenta ainda que "o dinheiro não deixa transparecer a espécie de mercadoria nele convertida. Qualquer mercadoria, ao assumir a forma dinheiro, é igualzinha a qualquer outra". Segundo Marx, a "magia do dinheiro" está na capacidade deste em fazer desaparecer todo um conjunto de relações sociais que, em intercâmbio, possibilitam a acumulação de capital. $\mathrm{O}$ valor "transforma cada trabalho num hieróglifo social" (Marx, 1985, p. 285, 122, 81), que pode e precisa ser decifrado.

O que propomos inicialmente é um "estranhamento" em relação à produção de mercadorias, pois se "à primeira vista, a mercadoria parece ser coisa trivial, imediatamente compreensível, analisando-a, vê-se que ela é algo muito estranho, cheio de sutilezas metafísicas e argúcias teológicas". O "caráter

(4) Para alguns moradores de Cuiabá, a troca de ouro por chumbo não foi uma fraude, mas uma "metamorfose" operada pela "divina justiça pelas lágrimas dos miseráveis que entregavam as fazendas por não terem com que pagar os direitos delas” (Sá, 1975, p. 24). 
fetichista" ${ }^{, 5}$ da mercadoria-ouro decorre, assim, como o das outras mercadorias, "do caráter social próprio do trabalho que produz mercadorias". Para Marx, o fetichismo encobre de mistério as relações que possibilitaram a produção das mercadorias (Marx, 1985, p. 79-80).

Para analisarmos o "fetichismo" da mercadoria-ouro não trataremos das relações sociais envolvidas diretamente na exploração do ouro, como o trabalho escravo (negro e indígena) e, em menor medida, do de livres pobres. Abordaremos aspectos da economia e da sociedade que revelam elementos do processo de formação da sociedade colonial no centro da América do Sul.

O intendente Manuel Rodrigues Torres informou que na monção geral de 1740 foi enviado de Cuiabá com destino final a Lisboa o ouro referente a três matrículas da capitação.

Tabela 1

Valores da capitação referente à segunda matrícula de 1739.

\begin{tabular}{|c|c|}
\hline Referência & Valor em oitavas \\
\hline 3.170 escravos & $7.528 \%$ \\
\hline 85 escravos com multa & $2213 / 4$ e 14 grãos \\
\hline Ofícios & 137 3/4 e 1 grão \\
\hline Forros e livres que mineram & 223 e 7 grãos \\
\hline Lojas, boticas e cortes de carne & $3083 / 44$ grãos \\
\hline Vendas & $841 / 411$ grãos \\
\hline Livro de denúncias & $521 / 44$ grãos \\
\hline Do livro da primeira matrícula de escravos adventícios & $223 / 44$ grãos \\
\hline Do livro da primeira matrícula das lojas, boticas, vendas e cortes de carne & $12 \% / 412$ grãos \\
\hline Total & 8.592 e 17 grãos \\
\hline
\end{tabular}

Fonte: Relação (cópia) do ouro da Real Capitação. Vila Real do Senhor Bom Jesus do Cuiabá, 1209-1740; mss., microfilme Rolo 03, doc. 137 (AHU) - NDIHR/UFMT.

(5) Neste texto utilizaremos o termo fetiche e derivados apropriando-se do conceito de Marx de fetichismo da mercadoria, como o caráter misterioso que as mercadorias como produto do trabalho assumem nas relações sociais, como podemos inferir dos seguintes trechos: "O caráter misterioso que o produto do trabalho apresenta ao assumir a forma de mercadoria, donde provém? Dessa própria forma, claro. A igualdade dos trabalhos humanos fica disfarçada sob a forma de igualdade dos produtos do trabalho como valores; a medida, por meio da duração, do dispêndio de força humana de trabalho toma a forma de quantidade de valor dos produtos do trabalho; finalmente, as relações entre os produtores, nas quais se afirma o caráter social dos seus trabalhos, assumem a forma de relação social entre os produtos do trabalho" (Marx, 1985, p. 79-80). Em outro trecho: "Assim, no mundo das mercadorias, acontece com os produtos da mão humana. Isso eu chamo o fetichismo que adere aos produtos de trabalho, tão logo são produzidos como mercadorias, e que, por isso, é inseparável da produção de mercadorias. Esse caráter fetichista do mundo das mercadorias provém, como a análise precedente já demonstrou, do caráter social peculiar do trabalho que produz mercadorias" (Marx, 1996, p. 199). Deixemos claro, contudo, que não pretendemos ser absolutamente fiéis ao modo como o conceito é utilizado por Marx em toda a sua obra. Embora esta análise deva muito à obra de Marx, não nos propusemos a aplicar um modelo explicativo marxista ao corpo documental que analisamos. Nosso objetivo é operar a apropriação de algumas das reflexões de Marx que, a nosso ver, convergem com as reflexões da historiografia contemporânea e contribuem para o debate da historiografia econômica brasileira. 
Geralmente esta quantia das capitações é referenciada pelos historiadores como o índice de ouro que a metrópole lucrou com a produção aurífera (Simonsen, 1978; Pinto, 1979). O valor da "capitação e censo" não corresponde a uma parte do ouro extraído das minas que, como recurso natural valioso, era enviado para a metrópole. Antes de tudo é preciso ter a percepção de que os metais preciosos, como equivalentes gerais, "já saem das entranhas da terra como encarnação direta de todo trabalho humano" (Marx, 1985, p. 104), ou seja, os números da capitação não correspondem diretamente à quantidade do ouro extraído nas minas que cabia à Fazenda Real, mas sim a uma quantia de trabalho humano, utilizado tanto nas atividades de extração mineral como em outras atividades econômicas. Além de, como as outras mercadorias, encobrir as relações que possibilitaram sua produção, o ouro tem a especificidade de ser também um equivalente geral, ou seja, moeda, dinheiro.

Essa capitação correspondia às minas do Cuiabá e às minas do Mato Grosso. Não tivemos contato com o livro de registro para especificar o rendimento de cada localidade, mas os indícios mostram que a maior parte do valor das capitações é correspondente às "Minas do Cuiabá". João Gonçalves da Fonseca aponta que no livro de registro da capitação estavam matriculados 1.100 escravos nas minas do Mato Grosso (Fonseca, 2001, p. 16), valor que corresponde a pouco menos de $32 \%$ do total de escravos matriculados no termo da Vila Real.

Percebemos que além da capitação dos escravos, outros itens compõem a lista da arrecadação de tributos, como ofícios, lojas, vendas, boticas e cortes de carne, num valor que corresponde a pouco menos de $9 \%$ do total. Como valor, o total dos itens pode ser visto como irrisório, mas como indício é significativo, pois o valor em dinheiro "dissimula o caráter social dos trabalhos privados e, em consequência, as relações sociais entre os produtores". Os produtos do trabalho "adquirem (...) como valores, uma realidade socialmente homogênea, distinta da sua heterogeneidade" (Marx, 1985, p. 84, 82).

Mesmo que fossem apenas $9 \%$ dos rendimentos da Coroa que proviessem de outras atividades que não a extração aurífera, poderíamos afirmar que no ouro que partia para Portugal na capitação estavam "grudadas" relações de trabalho que embora monetariamente correspondessem a um pequeno percentual, envolviam uma parcela significativa da população, que não pode ter sua história, mesmo do ponto de vista econômico, reduzida a índices de valor monetário.

Veremos, todavia, que os valores das atividades não diretamente ligadas à mineração correspondem a um percentual bem mais expressivo dessa capitação. Segundo José Gonçalves da Fonseca, dos 1.100 escravos "que constam pelo livro da matrícula da capitação (...) somente seiscentos é que poderão empregar nas faisqueiras e nas lavras, por se ocupar o resto de lavouras de mantimentos" 
(Fonseca, 2001, p. 16). Portanto, 500 escravos nas "minas do Mato Grosso", dos quais foram cobradas taxas de capitação, não se ocupavam da produção aurífera.

Seria muito arbitrário aplicar a mesma relação entre escravo das minas e escravo das lavouras para as minas do Cuiabá. No entanto, no mesmo relato, Fonseca aponta que havia nas imediações da Vila Real dezesseis engenhos (Fonseca, 2001, p. 34). Apesar de não estarem desenvolvendo atividades mineiras, os senhores de engenho pagavam a capitação sobre os seus escravos ${ }^{6}$. Levando em conta que, em média, havia de 20 a 30 trabalhadores escravos por engenho ${ }^{7}$, tomando o número de 25 como média teríamos cerca de 400 escravos.

A estimativa mínima de mão de obra escrava em atividades rurais matriculada na capitação seria de 900 escravos, correspondendo a pelo menos $28,4 \%$ da renda total obtida com a matrícula de escravos. Somando-se o valor aproximado de 2.137 oitavas da capitação destes escravos com 766 oitavas de outras atividades econômicas (boticas, vendas, lojas, etc.), temos o número de 2.903 oitavas, que corresponde a $33 \%$ do total da renda da capitação. Valor sem dúvida significativo, mesmo para os historiadores da economia que confundem importância econômica com índice monetário.

Não é apenas na capitação que homens e mulheres, escravos e livres pobres do campo, imprimiram suas marcas no ouro que era enviado para Portugal. No pagamento dos direitos dos dízimos e das entradas (que correspondem ao imposto sobre a produção rural e da entrada de mercadorias em áreas mineradoras), é possível perceber a dimensão das atividades rurais e do comércio no centro da América do Sul.

Esses direitos muitas vezes não eram cobrados diretamente pela Coroa, ficando ao encargo de sociedades ou particulares, que arrematavam os contratos de cobrança desses tributos. Tais contratos têm sido analisados de forma mais atenta em trabalhos recentes. O estudo de Sampaio, por exemplo, analisando os contratantes do Rio de Janeiro, afirma que "a contratação de rendimentos e monopólios régios constituía (...) um poderoso instrumento de acumulação e de influência (...) propiciando a formação de uma elite" (Sampaio, 2001, p. 98).

Em uma carta enviada ao rei em 1722, o governador da capitania de São Paulo escreve ao governador do Rio de Janeiro comunicando que os dízimos de Cuiabá nesse mesmo ano foram arrematados por 18:000\$00 anuais, um valor exorbitante para a época. Na mesma carta, o governador de São Paulo aponta que

(6) Carta de Luiz de Mascarenhas ao rei D. João V. São Paulo, 03-10-1744; mss., microfilme Rolo 02, doc. 184 (AHU) - NDIHR/UFMT. JUNTA da câmara da Vila Boa de Goiás. Vila Boa de Goiás, 23/05/44; mss., microfilme Rolo 02, doc. 184 (AHU) - NDIHR/UFMT.

(7) Carta do ouvidor João Gonçalves Pereira ao rei D. João V; Vila Real do Senhor Bom Jesus do Cuiabá, 07-10-1736; mss., microfilme Rolo 01, doc. 89 (AHU) - NDIHR/UFMT. 
no princípio da exploração nas minas das Gerais, nunca os dízimos destas, somados com os dízimos de São Paulo, ultrapassaram 7:200\$000 ${ }^{8}$. Os dízimos do Rio de Janeiro em 1712 foram arrematados por 13:333\$333 anuais. O valor deste primeiro contrato pode ser justificado pelos altíssimos preços dos produtos agrícolas. Os valores dos contratos posteriores são muito diferentes. Ao longo da primeira metade do século XVIII, mantiveram-se estáveis em torno de 5:800\$000 anuais ${ }^{9}$. Estudos como o de Helen Osório sobre a arrematação de contratos reais podem nos auxiliar a relacionar esses valores com os contratos de outras regiões da América Portuguesa:

O contrato dos dízimos do povoado de Santos, São Paulo e Rio Grande de São Pedro foi arrematado por Pedro Gomes Pereira, em 1747, por 10:600\$000 anuais, não sendo discriminado o montante relativo a cada uma das áreas. Na arrematação seguinte, em 1750, houve especificação de valores: de um total de $10.815 \$ 000$, correspondiam ao Rio Grande e Santa Catarina 30\% deste valor, e a São Paulo e Paranaguá, 70\% (Osório, 2001, p. 111).

Fazendo as contas, os dízimos de São Paulo e Paranaguá, em 1750, correspondem ao valor de 7:570\$000 e os de Rio Grande e Santa Catarina a 3:244\$000. Valores que colocam o contrato dos dízimos de Cuiabá em posição intermediária. No entanto, em relação aos contratos dos dízimos arrematados em Minas Gerais, Rio de Janeiro, Pernambuco e Bahia, o valor do contrato das "minas do Cuiabá" é bem menor.

Tabela 2

Dízimos da Bahia, Pernambuco, Rio de Janeiro e Cuiabá: 1727-1742 - em mil-réis.

\begin{tabular}{c|c|c|c|c}
\hline Anos & Bahia & Pernambuco & Rio de Janeiro & Cuiabá \\
\hline 1727 & $72: 050$ & $20: 000$ & $16: 900$ & $5: 800$ \\
\hline 1729 & $72: 050$ & $20: 500$ & $18: 920$ & $6: 800$ \\
\hline 1741 & $52: 420$ & $11: 260$ & $19: 205$ & $6: 920$ \\
\hline 1742 & $52: 420$ & $11: 260$ & $19: 208$ & $6: 920$ \\
\hline
\end{tabular}

Fonte: Florentino e Fragoso (2001, p. 246, adaptado). RELAÇÃO de todos os contratos dos dízimos respectivos à comarca da Vila de Cuiabá; post. 01-10-1764; mss., microfilme, Rolo 12, doc. 729 (AHU) - NDIHR/UFMT.

Se desprezarmos os valores absolutos e nos ativermos à renda dos dízimos por habitante, os valores se invertem, dada a disparidade demográfica das regiões.

Apesar de, como salientou João Fragoso, a arrematação de contratos envolver "negociações entre funcionários do rei e os arrematadores" (Fragoso,

(8) Carta de Rodrigo César de Menezes ao governador do Rio de Janeiro. São Paulo, 02-05-1722; mss., livro C001 doc. 42, APMT.

(9) Relação (cópia) do ouro da Real Capitação. Vila Real do Senhor Bom Jesus do Cuiabá, 12-09-1740; mss., microfilme Rolo 03, doc. 137 (AHU) - NDIHR/UFMT. 
2001, p. 65) que não são necessariamente pautadas em questões puramente econômicas, acreditamos que os valores podem ser, levando em conta inclusive essas "negociações", indícios da produção e da circulação de mercadorias.

Também os direitos das entradas fornecem indícios importantes. Em 1740, o valor anual do contrato para os caminhos que ligavam as minas da capitania de São Paulo era de 22 arrobas e meia libra de ouro ${ }^{10}$. O valor do mesmo contrato para os caminhos que ligavam Rio de Janeiro a Minas Gerais era, no mesmo ano de 1740 , de 50 arrobas - mais que o dobro -, enquanto para os caminhos que por Pernambuco e Bahia chegavam a Minas Gerais, o valor era de 34 arrobas. Somando-se todos os valores, os direitos das entradas rendiam à Coroa 106 arrobas e meia libra de ouro. O percentual que corresponde às minas da capitania de São Paulo é pouco mais de $22 \%$, valor bastante expressivo, haja vista a diferença nos índices demográficos entre as regiões.

Quem mais lucrava com os contratos, obviamente, eram os contratadores. Segundo Helen Osório, "os contratos eram mais lucrativos que os engenhos e o tráfico de escravos" (Osório, 2001, p. 116). Mas, além de demonstrar um dos mecanismos utilizados pela elite colonial e metropolitana para acumular capital, a análise dos contratos mostra que o "conjunto de lavradores, comerciantes e artífices" formava um "circuito de acumulação de rendas" (Fragoso, 2001, p. 65) que de acordo com os valores expressados é monetariamente significativo, mas, principalmente, é revelador de uma série de atividades econômicas essenciais para a reprodução da sociedade colonial.

Por meio da análise do fetichismo da mercadoria-ouro, conseguimos reconstruir alguns laços que ligavam as atividades econômicas reproduzidas no centro da América do Sul a uma história monetária tão evidenciada por Godinho, Mauro e Vilar. Se uma parte da riqueza produzida nas minas do Cuiabá e do Mato Grosso iam, em forma de ouro, com destino à Lisboa, o que acontecia com a riqueza que os tributos reais e eclesiásticos não conseguiam levar? As análises de Osório e Sampaio, como vimos, destacaram o papel dos contratos na formação de elites, o que é plenamente demonstrável em suas análises. No entanto, essa acumulação por parte de agentes coloniais é apenas um ponto intermediário dos circuitos de acumulação do capital mercantil. A menos que admitamos a hipótese de que toda essa riqueza permanecesse na América Portuguesa, havia outros meios para escoá-la para além do continente americano. Na análise que fizemos até agora é possível inferir que era através do comércio que essas mercadorias, não necessariamente com suas propriedades físicas, mas principalmente em forma de valor, ligavam-se a redes mercantis que atravessavam o oceano Atlântico e chegavam à Europa, à África e à Ásia.

(10) Termo de Arrematação (cópia) dos rendimentos das entradas para as minas da capitania de São Paulo. Lisboa, 29-01-1742; mss., microfilme Rolo 03, doc. 160 (AHU) - NDIHR/UFMT. 


\section{Acumulação endógena $x$ Sistema colonial: modelos rivais?}

Segundo João L. Fragoso, a economia colonial possuía movimentos de acumulação endógena, o que possibilitou a existência de uma elite mercantil na colônia. A análise de Fragoso parte dos seguintes pressupostos:

a) a existência de uma formação econômica e social no espaço colonial, resultado da interação do escravismo com outras formas de produção não capitalistas;

b) a presença de um mercado interno que, sendo consequência da recorrência daquela formação econômico-social e permitindo a retenção de parte do sobretrabalho colonial, daria margem à realização de acumulações endógenas;

c) a ação de uma elite mercantil, originária de tais acumulações endógenas e "responsável" pela produção da agroexportação, à qual caberia promover o controle de parte do excedente retido na formação colonial;

d) o fato de que a economia colonial, mais do que uma plantation escravista, é a base de uma sociedade com uma dada hierarquia econômico-social), sendo seu principal objetivo, seu sentido, se assim preferirmos, reiterar no tempo tal sociedade - desse modo, a inversão do sobretrabalho não mais dependeria apenas de injunções externas, mas, antes de mais nada, estaria subordinada às necessidades de reprodução da estrutura social considerada (Fragoso, 1998, p. 157).

Antes de qualquer crítica à análise desse autor, é necessário apontarmos aspectos que contribuem significativamente para a percepção mais clara do funcionamento da economia colonial. Fragoso construiu uma análise que teve o mérito de introduzir no debate, por meio de uma densa pesquisa documental e uma profunda reflexão historiográfica, as formas de produção não voltadas necessariamente para a agroexportação como partes integrantes e fundamentais para a reprodução da economia e da sociedade coloniais e para a acumulação de capitais $^{11}$. Sobre os segmentos camponeses, por exemplo, em relação às Minas Gerais, Fragoso afirma:

A maior parcela dessa força de trabalho livre estava associada a seus meios de produção, e em alguns casos recorrendo a escravos, com plantéis que majoritariamente iam de um a cinco cativos; cerca de 39\% dos proprietários de Minas detinham plantéis com menos de três escravos (cerca de $9 \%$ de população cativa). Esse padrão de propriedade escrava, confrontado com os traços que definem uma unidade como camponesa, nos leva a crer, como já dissemos, que em Minas Gerais parte da sua produção enviada ao mercado interno era resultado de unidades camponesas; fenômeno que, aliás, como vimos, já poderia ser encontrado no século XVIII. Em outras palavras, por uma forma de produção cuja lógica de funcionamento não se reduzia apenas à possibilidade de extorsão de sobretrabalho do outro, no caso do cativo, mas também ao próprio grau de autoexploração do

(11) Obviamente, Fragoso não foi o primeiro a reivindicar a relativa autonomia da dinâmica interna da Colônia, contudo a densidade da pesquisa documental e o volume das pesquisas do autor nessa área sem dúvida reaqueceram o debate. 
dono do escravo. Esse fenômeno, evidentemente, distinguia esse senhor de escravos de Minas, em seu cálculo econômico, daquele que tinha atrás de si dezenas de cativos (Fragoso, 1998, p. 134).

Outra questão importante tratada por Fragoso é a da vinculação entre a economia e as formações sociais. O autor destaca a importância da estrutura social engendrada na Colônia para a reprodução econômica, rejeitando algumas simplificações quanto à relação entre a demanda da economia internacional e a formação da sociedade colonial (Fragoso, 1998, p. 156).

O ponto frágil da análise de Fragoso está, a nosso ver, na discussão sobre a articulação entre o mercado interno, o setor agroexportador e o capitalismo comercial europeu. O próprio autor reconhece que "não há como negar certas evidências presentes no mundo colonial", como por exemplo, "sua inserção no mercado internacional"; "a transferência de fração do sobretrabalho colonial" e "a impossibilidade de se executarem acumulações autocentradas em condições coloniais (realização externa de parte do excedente econômico)" (Fragoso, 1998, p. 156). Os termos "fração" e "parte" são vagos em termos lógicos e não definem o grau de "inserção" quanto mais a importância da "realização externa". Fragoso construiu sua análise opondo-se à concepção de "Sistema Colonial", ou "Antigo Sistema Colonial", que remete aos trabalhos de Caio Prado Júnior e principalmente de Fernando A. Novais.

Para resumirmos de uma forma que inevitavelmente diminui muito a complexidade da análise de Novais, poderíamos definir o Antigo Sistema Colonial como parte integrante das relações no contexto do que se convencionou chamar de Antigo Regime, assim como o capitalismo comercial, a expansão ultramarina e a política mercantilista (Novais, 1986, p. 66).

Ao sentido atribuído por Caio Prado Júnior à colonização, Novais acrescenta a vinculação com a etapa de transição do feudalismo para o capitalismo e, consequentemente, "o sistema colonial em funcionamento configurava uma peça da acumulação primitiva de capitais nos quadros do desenvolvimento do capitalismo comercial europeu". O ponto fundamental para Novais do sistema colonial era o "exclusivo metropolitano", ou o "monopólio régio português", que embora garantisse a condição colonial, não impedia que grande parte dos excedentes adquiridos através do monopólio "se transferissem para fora do reino" ${ }^{\prime 2}$ (Novais, 1986, p. 68, 92, 74).

Em um texto mais recente, de 1997, Novais de forma bastante pontual, em nota de rodapé, num artigo da coletânea organizada por ele próprio, História da

(12) “O monopólio régio português, garantia, assim, condições favoráveis à economia européia em geral, promovendo a aceleração da acumulação de capitais mercantis: na engrenagem do sistema contudo, as maiores vantagens se transferiam para fora do reino" (Novais, 1986, p. 74). 
vida privada no Brasil, rebateu algumas das críticas de Fragoso e de outros autores em relação ao seu "esquema interpretativo". Novais reitera que "acumulação para fora, externa, refere-se à tendência dominante do processo de acumulação, não evidentemente à sua exclusividade" e afirma que "alguma porção do excedente devia permanecer ('capital residente') na Colônia, do contrário não haveria reprodução do sistema". Em outro trecho, rebate: "Não cabe, portanto a increpação de obsessão com as relações externas (porque não estamos falando de nada externo ao sistema), nem desprezo pelas articulações internas, pois estas não são incompatíveis com aquelas". Para Novais, "trata-se, simplesmente, de enfatizar um ou outro lado, de acordo com os objetos de análise" e, por último, questiona: "Se não são estas as características (extroversão, externalidade da acumulação, etc.) fundamentais e definidoras de uma economia colonial, o que, então as define? Ou será que se não definem? Será que nada de essencial as distingue das demais formações econômicas?" (Novais, 1997, p. 448).

Parte da produção histórica brasileira, embora parta de pressupostos que atribuem uma característica endógena para a reprodução econômica colonial, mostra exatamente o contrário, ou seja, a vinculação estrutural da produção para o abastecimento interno e a "extroversão", ou "externalidade da acumulação" (NOVAIS, 1997, p. 448). É o caso, por exemplo, para tratarmos da primeira metade do século XVIII, do trabalho de Jucá de Sampaio. O autor destaca que a crise do setor açucareiro no Rio de Janeiro gerou um investimento dos "homens de negócio no agro fluminense" em setores ligados ao "abastecimento interno". Segundo Sampaio (2001),

o quadro resultante da análise dos investimentos dos homens de negócio no agro fluminense desse período é, à primeira vista, surpreendente. Não seria exagerado afirmar que eles desprezam a possibilidade de se transformarem em membros da elite agrária em favor do investimento em produções bem menos "nobres", posto que voltadas para o abastecimento interno. De fato, ao investirem nessa produção, os negociantes cariocas tinham seus olhos voltados para a forte demanda então existente. Demanda essa que tinha origem em três mercados fundamentais: as áreas mineradoras, a urbe carioca e os navios que aí aportavam, e que se destinavam às diversas regiões do império lusitano. Abastecê-los significava, para essa elite mercantil, o fortalecimento de suas ligações com essas mesmas áreas.

O que podemos inferir dessa análise de Sampaio, talvez contrariando alguns de seus pressupostos, é que os mecanismos de exploração do capital mercantil, sempre e de forma estrutural mediados pelo sistema colonial, encontram alternativas para investimentos lucrativos. A "elite" que controlava diretamente essa produção certamente não era a principal beneficiária dos lucros advindos com a circulação dessas mercadorias, a menos, obviamente, que essa mesma "elite" dominasse além da produção também o comércio. Um ponto do artigo de Sampaio com o qual estamos de pleno acordo é que a economia colonial não pode ser 
explicada apenas por fatores externos e que a ênfase da análise sobre os setores agroexportadores prejudicou a percepção da diversidade da economia rural, e que, consequentemente a existência de um "renascimento agrícola" no último quarto do século XVIII deve ser questionada, com base nas pesquisas recentes (Sampaio, 2001, p. 99-100, 127) ${ }^{13}$.

No entanto, a inversão da produção do setor agroexportador para o mercado interno não significou a introversão da acumulação, mas, ao contrário, revelou que os mecanismos de extroversão agem também sobre esse setor. Uma comprovação desse fato, sem grandes esforços de pesquisa empírica, é a flagrante ligação entre a expansão desse setor e o tráfico internacional de escravos.

Concordando ou não com a noção de "Antigo Sistema Colonial" ou com o "sentido da colonização", é imprescindível, para uma crítica mais substancial, uma leitura atenta da obra de Novais. Em Portugal e Brasil na crise do Antigo Sistema Colonial, o autor afirma a existência de uma produção "que visava suprir a subsistência interna":

É claro que ao lado dessa produção essencial para o mercado europeu, organizavase nas colônias todo um setor, dependente do primeiro, da produção que visava suprir a subsistência interna daquilo que não podia ser aprovisionado pela metrópole. Mas, ainda aqui, são os mecanismos do sistema colonial que definem o conjunto e imprimem o ritmo em que se movimenta a produção (Novais, 1986, p. 96).

O ponto decisivo, portanto, não é a existência ou não de um mercado interno que possuía investimentos mercantis (o que, de fato, foi pouco enfatizado por Novais, que privilegiou a análise dos setores exportadores por excelência), mas a importância e a caracterização deste mercado interno e da base social que se organizava em torno do abastecimento. Nesse sentido, são várias as críticas que podemos fazer à tese de Novais, e não poderia ser diferente, já que no princípio da década de 1970, quando Novais concluiu sua tese, os estudos sobre a produção para o abastecimento do mercado interno colonial e sobre a circulação de mercadorias no interior da América Portuguesa eram escassos, sem falar em questões de ordem teórico-metodológicas.

Nosso objetivo não é criticar a noção de "Sistema Colonial" para descartála, mas revisitar alguns pontos críticos na formulação dessa noção. Vejamos duas questões significativas para nossa análise. A primeira diz respeito à relação entre a reprodução econômica e a estrutura social. Assim como Caio Prado, Novais

(13) Embora a afirmação de Sampaio de que "os estudos que buscam fornecer uma visão geral da agricultura brasileira durante os séculos XVII e XVIII ainda encontram-se excessivamente presos aos marcos da agroexportação, incapazes de enxergar uma economia rural que ia muito além dos engenhos de açúcar" seja generalizante e simplifique a contribuição da historiografia, tal ênfase é inegável. 
reforça que o "sentido da colonização" está na exploração de atividades voltadas para o mercado externo. Novais (1986) afirma de forma categórica que

toda a estruturação das atividades econômicas coloniais, bem como a formação social a que serve de base, definem-se nas linhas de força do sistema colonial mercantilista, isto é, nas suas conexões com o capitalismo comercial (p. 97).

Apesar do nosso artigo não estar inserido propriamente no campo da história social, é necessário reconhecer que a relação entre a economia e a sociedade pode ser analisada de forma mais complexa. Obviamente a passagem que escolhemos expõe parcialmente a análise de Novais sobre essa relação, já que o próprio autor afirma que embora "o sentido do movimento" seja "a primitiva acumulação capitalista" este não está "presente em todas as manifestações, mas imanente em todo o processo" (Novais, 1986, p. 97), o que dá margem para uma interpretação mais maleável, mas que não é suficiente para compreender a forma como a sociedade se articula com o sistema colonial da Época Moderna. A utilização de termos para tratar dessa relação economia/sociedade como "ajuste", "reflexo", "determinação" faz com que a sociedade pareça muitas vezes "subordinada" aos "mecanismos", "quadros", "esquemas" do sistema colonial $1^{14}$, o que à primeira vista é plenamente compreensível já que é inegável que a colonização é um processo de conquista e de exploração, mas olhando mais de perto, percebem-se "resistências" e "estratégias" que não apenas expressam uma "adaptação" ao Sistema Colonial, mas relações de poder, que, mesmo assimétricas, imprimiam suas marcas na reprodução deste ${ }^{15}$.

O segundo ponto é que as análises, tanto de Caio Prado Júnior como de Fernando Novais, atribuíram um lugar ao mercado interno que não corresponde como indicam os trabalhos mais recentes -, à importância real que a reprodução deste tinha para a acumulação de capital, não apenas, ou não fundamentalmente, no interior da Colônia, mas subestimaram, sobretudo, o índice de "extroversão" do excedente econômico, ou do sobretrabalho, das atividades voltadas ao abastecimento do mercado interno, assim como da produção não "tipicamente" mercantil de mercadorias para o mercado externo, como apontam as pesquisas recentes sobre Pernambuco, Bahia e Rio de Janeiro.

Nesse ponto, nossa análise "radicaliza" o "sentido da colonização" (do ponto de vista econômico) mostrando que este se manifesta diretamente na

(14) Ver Novais (1981).

(15) Não podemos afirmar se Novais hoje ainda manteria a utilização desses termos, mas no texto de 1997, já citado, o autor não utiliza nenhum desses termos para caracterizar a relação entre economia e sociedade. Aliás, Novais não faz nenhuma alusão à relação entre economia e sociedade, afirma que "extroversão" e "externalidade da acumulação" são características da "economia colonial", não estende a afirmação à sociedade, e depois usa "formação econômica" para especificar a condição colonial (Novais, 1997, p. 448, nota 15). 
produção e circulação de mercadorias no interior da América Portuguesa, e que na sua forma-valor esta "economia interna" externaliza-se como demonstramos na análise sobre ofetiche da mercadoria.

José J. de A. Arruda (1980) em O Brasil no comércio colonial afirma que

provar que o líquido da exploração colonial é considerável em termos de valor, e que extravasa em direção ao centro do sistema promovendo a acumulação primitiva, é uma forma de penetração da estrutura da economia colonial. Do mesmo modo, mostrar que o mercado colonial é indispensável para sustentar o ritmo do crescimento econômico da Metrópole também é penetrar na essência do sistema (p. 27).

Embora nossa ênfase recaia, ao contrário de Arruda, nos setores não ligados diretamente à exportação, argumentamos que uma análise da produção "internalizada", desde que se atente para os mecanismos de "externalização", também permite a "penetração da estrutura da economia colonial" e "na essência do sistema", já que a produção não exportadora, longe de uma simples oposição ao escravismo e ao latifúndio, articulava-se a estas características. Schwartz aponta que a escravidão, "mesmo que de maneira cruel, mostrava-se perfeitamente adaptável" à produção voltada para o mercado interno, mesmo à camponesa (Schwartz, 1999, pp. 123-153). Para o autor, "a produção de roceiros e escravos, ou, com maior exatidão, a agricultura de subsistência e de exportação, estavam intimamente ligadas numa relação complexa, multidimensional e em mutação histórica", ou seja, "tanto uma como outra forma de produzir "eram, de fato, duas faces da mesma moeda" (Schwartz, 2001, p. 125).

\section{O centro da América do Sul no âmbito da economia-mundo}

Como apontou José Jobson de Andrade Arruda, "a questão de fundo" na discussão sobre a relação entre produção colonial, sistema colonial e a vinculação ao processo de acumulação primitiva de capitais "é a própria natureza do capital mercantil” (Arruda, 2000, p. 168). Fernand Braudel, em Civilização material, economia e capitalismo: Séculos XV-XVIII, oferece uma perspectiva bastante esclarecedora, articulando a produção voltada para o abastecimento a uma economia-mundo europeia. Marx e Engels, já na Ideologia Alemã apontavam para "a transformação da história em história mundial". No entanto, Braudel parte de uma perspectiva diferente daquela desenvolvida por Marx tanto em $O$ capital como em seus trabalhos anteriores. Apesar de afirmar que a transformação da história em história mundial era "ato totalmente material, demonstrável empiricamente, um ato cuja prova é fornecida por cada indivíduo no seu dia-a-dia, ao comer, ao beber, e ao vestir-se" (Marx; Engels, 1984, p. 44), o autor de $O$ capital não avança na caracterização dessa materialidade, o que parece ser, a 
começar pelo título, o principal objetivo de Braudel nos três volumes dessa extensa obra.

Braudel atribuiu especial importância aos "jogos monetários" e/ou "o jogo das trocas" e analisou as atividades comerciais em áreas de mineração na América. Sobre o comércio de abastecimento Braudel (2005), afirma:

O mercador local, primeiro. Como na Europa, as populações mineiras instalam-se no ermo, como no norte do México; ou num verdadeiro deserto, no Peru, no coração das montanhas andinas. A grande questão é, portanto, o abastecimento. Ela já se colocava na Europa, onde o empresário fornecia os víveres necessários ao mineiro e ganhava muito com este tráfico. Na América, o abastecimento domina tudo. É o caso dos garimpos brasileiros. É o caso do México, onde as minas do norte exigem grandes remessas de gêneros provenientes do sul. (...) Ora, aqui não é o mineiro (proprietário que explora as minas) que assegura o próprio abastecimento. O mercador adianta-lhe a troco de ouro ou de prata, víveres, tecidos, ferramentas, mercúrio, aprovisionando-o em um sistema de escambo ou de comandita. É o dono indireto, descrito ou não, das minas. Mas não o senhor último destas trocas que as diversas etapas de uma cadeia mercantil comandam, em Lima, no Panamá, nas grandes feiras de Nombre de Dios ou de Porto de Belo, em Cartagena de las Índias, finalmente em Sevilha ou em Cádiz, pontos de partida de uma outra rede européia de redistribuição. (...) É aí, ao longo de todo o percurso e das fraudes por ele permitidos, que se situam os lucros - não tanto na fase de produção mineira (p. 285286).

A análise de Braudel, por se desenvolver em uma escala muito ampla, não consegue escapar da homogeneização e da generalização de processos históricos distintos, mas, mesmo assim, a contribuição desse autor é bastante significativa, principalmente, por demonstrar os caminhos que as trocas desenhavam até chegar à Europa. Mesmo em atividades aparentemente voltadas apenas para o mercado interno, ou mesmo local, havia a articulação com uma economia-mundo que desde o século XVI expandia-se e incorporava novos territórios. Neste ponto, a formulação de Braudel sobre "o abastecimento" é completamente diversa das percepções sobre a "economia de subsistência" elaboradas por Caio Prado Júnior ${ }^{16}$ e também por Celso Furtado ${ }^{17}$ e apropriadas em várias análises sobre a economia colonial. A diferença fundamental é a percepção de Braudel sobre as

(16) Para Caio Prado Júnior (1997), "na agricultura colonial brasileira é preciso distinguir dois setores cujo caráter é completamente diverso. (...) De um lado, a grande lavoura, seja ela do açúcar, do algodão ou de outros gêneros de menos importância, que se destinam ao comércio exterior. Doutro, a agricultura de 'subsistência', isto é, produtora de gêneros destinados à manutenção da população do país, ao consumo interno. (...) Aqueles gêneros de consumo são produzidos, na maior parte dos casos, nos mesmos estabelecimentos rurais organizados e estabelecidos para cuidar da grande lavoura. Destinam-se a abastecer o pessoal empregado nesta última, e existem portanto unicamente em função dela" (p. 142-143).

(17) Para Celso Furtado (2003), particularmente em relação às minas do Cuiabá e do Mato Grosso, "uns poucos decênios foram suficientes para que se desarticulasse toda a economia da mineração, decaindo os núcleos urbanos e dispersando-se grande parte de seus elementos numa economia de subsistência, espalhados por uma vasta região em que eram difíceis as comunicações e isolando-se os pequenos grupos uns dos outros” (p. 91). 
características do capital mercantil. Braudel mostra a versatilidade do capital mercantil quanto à possibilidade de diversificação dos investimentos e, como consequência, esse operava na reprodução das mais diferentes atividades que, por consequência, se articulavam e se interligavam em relações econômicas mais amplas.

Apesar de a economia europeia representar o ponto mais dinâmico, "é em escala mundial que se projeta e se explica o sistema, vasta rede lançada sobre as riquezas dos outros continentes" (Braudel, 2005, p. 419) ${ }^{18}$. Braudel (2005) destaca o papel do crédito e da moeda para a configuração da economia mundial:

Tal como a navegação de alto-mar ou como a imprensa, moeda e crédito são técnicas, técnicas que se reproduzem, se perpetuam por si próprias. São a única e mesma linguagem que todas as sociedades falam a seu modo, que qualquer indivíduo é obrigado a aprender. Pode nem saber ler e escrever: só a alta cultura está sob o signo da escrita. Mas não saber contar seria ficar condenado a não sobreviver. A vida cotidiana é a escola obrigatória do número: o vocabulário do débito e do crédito, das trocas, dos preços, do mercado, das moedas oscilantes que envolve e confina qualquer sociedade um pouco evoluída. Estas técnicas tornaramse heranças que, obrigatoriamente, se transmitem pela via do exemplo e da experiência. Determinam a vida dos homens e o dia-a-dia, ao longo da existência, das gerações, dos séculos. Constituem um enquadramento dos homens à escala mundial (p. 436).

Esse "enquadramento à escala mundial" não exclui dinâmicas particulares, exclui sim a ideia de isolamento entre práticas econômicas, que embora não se articulem diretamente, possuem vínculos com uma economia-mundo em expansão e que se espacializa a partir, principalmente, do século XVIII, no centro da América do Sul.

A análise de um documento de comerciantes de Cuiabá na primeira metade do século XVIII ajuda a esclarecer a relação das atividades comerciais desenvolvidas no extremo oeste da América Portuguesa.

Com a descoberta das minas do Mato Grosso, tanto a mineração quanto as atividades comerciais na fronteira entre os territórios ibéricos ganhavam cada vez mais expressão. A percepção da proximidade com os territórios hispânicos por parte dos comerciantes de Cuiabá redimensionava as possibilidades de ampliação deste comércio e sua inserção em diferentes redes comerciais. Segundo Carlos A. Rosa, na primeira metade do século XVIII formou-se em Cuiabá "um grupo hegemônico". Carlos Rosa enumerou os seguintes instrumentos de acumulação por parte desse grupo: "a expropriação do trabalho indígena e o comércio do negro africano já expropriado"; "o investimento na expansão da exploração aurífera”;

(18) Braudel não percebe este processo de forma unilateral. Para o autor a Europa, "tem de jogar o jogo local onde quer que vá impor-se”. 
"esforço permanente com vistas ao acesso aos terminais da máquina estatal situados em Cuiabá"; "as tentativas explícitas ou dissimuladas de estabelecer um comércio intercolonial". Ainda segundo Carlos Rosa, "de todos esses itens, o último pode ser assumido como a manifestação mais orgânica do grupo hegemônico de Cuiabá" (Rosa, 1982, p. 37).

Em um longo documento datado de 20 de setembro de 1740, o ouvidor de Cuiabá corresponde-se com o rei, representando os interesses dos "comerciantes de Cuiabá". O ouvidor anexa à sua carta um abaixo-assinado desses comerciantes. Analisaremos este documento por partes:

Dizem os comerciantes das minas do Cuiabá na presente assinados uns por si, outros por seus bastantes procuradores, que eles têm experimentado, e atualmente estão padecendo diminuição muito grande de seus cabedais empregados em fazendas por não poderem dar-lhes saída nas ditas minas (...) o que procede do diminuto número de moradores, e falta de ouro por não ter quem o procure $(\ldots)^{19}$.

A argumentação inicial dos comerciantes não corresponde aos indícios que outros documentos do mesmo período deixam sobre o avanço da colonização tanto a oeste quanto para o norte do termo da Vila Real. Percebemos que este foi um período de vários descobertos auríferos e de ampliação do número de ambientes coloniais portugueses no centro da América do Sul. Os dados demográficos apontam o aumento regular e significativo de moradores no termo da Vila Real entre 1735 e 1745 (Rosa, 2003, p. 37).

Não queremos afirmar que os argumentos dos comerciantes são "inválidos", aliás não é nosso objetivo esse tipo de avaliação. Só ponderamos, mais uma vez, que os indícios documentais devem ser analisados de forma criteriosa. É provável, contudo, que os comerciantes de Cuiabá encontrassem dificuldades de ampliar seus negócios e reproduzir seu capital em virtude da impossibilidade do mercado local de acompanhar a perspectiva de crescimento e de ampliação de lucro dos comerciantes. Muitos, inclusive, poderiam estar endividados por terem adquirido fazendas a prazo.

A primeira questão que esse documento apresenta é que os "comerciantes de Cuiabá" constituíam um grupo social que lutava por seus interesses e que possuía vínculos com o poder local e conseguia apoio de autoridades metropolitanas, como o ouvidor João Gonçalves Pereira. Os comerciantes haviam comandado uma diligência para os territórios que julgavam estratégicos para o contato com os súditos de Castela, sob a alegação de que "para se poderem povoar é necessário explorar-se primeiro para servir no conhecimento de seus terrenos e capacidades".

(19) Abaixo-assinado dos comerciantes das minas do Cuiabá ao rei D. João V. Vila Real do Senhor Bom Jesus do Cuiabá, 20-09-1740; mss., microfilme Rolo 03, doc. 140 (AHU) - NDIHR/UFMT. 
Desde o princípio da colonização portuguesa no centro da América do Sul, os colonos tinham percepção da proximidade com os territórios hispânicos. No entanto, as atividades exploratórias (diligências, expedições) tornaram essa percepção mais concreta. No documento, os comerciantes procuraram articular seus interesses à "geografia política" de Portugal. O sistema administrativo português atribuía especial importância à dimensão territorial da conquista. Segundo o ouvidor, "fundaram os suplicantes à sua resolução no capítulo vinte e seis do regimento do vice-rei e governador geral deste Estado (Estado do Brasil) no qual determina v. majestade se povoem todos os domínios".

Tanto cuidado em justificar as práticas adotadas por esses comerciantes não era um simples recurso narrativo. Era com muito receio que o rei de Portugal e seus conselheiros em assuntos do ultramar viam as relações entre os súditos das coroas ibéricas. Posicionamento político que emanava do poder central e que se reproduzia nas relações locais de poder, desencadeando disputas e tensões. O intendente e provedor de Cuiabá, Manuel Rodrigues Torres, escreveu ao rei, no mesmo ano de 1740, denunciando o ouvidor João Gonçalves Pereira de ambicionar "entregar as minas aos castelhanos". O intendente e provedor ainda se queixava da "injusta prisão que sofria" ${ }^{20}$ por ordem do mesmo ouvidor.

O desdobramento dessas tensões não é o objeto deste artigo. A percepção da articulação destas aos interesses comerciais, contudo, mostra a expressão das atividades comerciais em âmbito local e a formação de uma elite de homens de negócio, voltados para as atividades comerciais. As tensões, inerentes às disputas de poder, entre defensores e opositores da abertura de comércio com os espanhóis, via centro da América do Sul, não se encerravam na câmara da vila de Cuiabá. Para termos uma noção da dimensão de tal proposta, o Conselho Ultramarino pediu pareceres dos governadores de São Paulo e do Rio de Janeiro, do procurador da Coroa e do provedor da Real Fazenda. Voltando ao abaixo-assinado,

(...) pessoas práticas no sertão como Antonio Pinheiro de Faria, Manuel Dias [ ] e outros, que saíram desta povoação no princípio do mês de julho do presente ano para [ ] indagar a distância que há destas minas do Cuiabá às primeiras povoações de sua majestade católica: fundaram os suplicantes a sua resolução no capítulo vinte e seis do regimento do vice rei e governador geral desse Estado no qual determina v. majestade se povoem todos os domínios e como para se poderem povoar é necessário explorar-se primeiro para servir no conhecimento de seus terrenos e capacidades, motivos pelos quais se dispuseram os suplicantes a concluir a dita diligência, e poderão seus habitantes ficar com contígua vizinhança aos moradores das povoações daquele monarca, e estas são subúrbios do opulentíssimo reino do Peru, sendo este abundante de riquezas, populosas vilas e cidades, como necessitado de fazendas e mais gêneros que os suplicantes conduzem a estas minas

(20) Carta do intendente e provedor Manuel Rodrigues Torres ao rei D. João V. Vila Real do Senhor Bom Jesus do Cuiabá, 17-08-1740; mss., microfilme Rolo 02, doc. 136 (AHU) - NDIHR/UFMT. 
para negócio - como o mundo todo conhece -, é certo que valendo-se os suplicantes da mercê que v. majestade tem feito a seus vassalos (...) que procurem comerciar com os castelhanos pelos meios que parecerem mais convenientes (...)

Os comerciantes buscavam articular seu interesse à geopolítica metropolitana, apropriando-se de enunciados dos discursos das cartas que o rei e o Conselho Ultramarino enviavam para Cuiabá. Para que houvesse expansão das conquistas portuguesas e efetivação de ambientes coloniais era imprescindível a presença efetiva de súditos do rei de Portugal. A permissão para comercializar com os castelhanos, porém, envolvia outros interesses que não podem ser entendidos apenas pela ótica geopolítica.

Os suplicantes argumentavam que, por meio do comércio, os castelhanos deixariam "parte do precioso de suas riquezas e muitos gados quadrúpedes, de que abundam as pampas paraguaianas". Mais do que apenas prever os efeitos imediatos e locais, os comerciantes apontavam consequências mais amplas desse comércio: 1) "aumentarão as povoações nestes tão dilatados estados de v. majestade"; 2) "terá multiplicados os direitos da real fazenda tanto nas alfândegas dos portos marítimos", 3) "terá maior aumento o contrato dos dízimos" 4) ampliação das lavouras para abastecer o comércio ${ }^{21}$.

Os apontamentos dos comerciantes e do ouvidor nos possibilitam perceber como os luso-americanos que se dedicavam ao comércio e outras atividades econômicas na parte mais central da América do Sul estavam interligados com as redes comerciais da América Portuguesa como um todo e previam as consequências positivas do empreendimento que propunham para toda a Colônia, e deixando ainda mais evidente a ligação já existente entre as praças comerciais do litoral atlântico. Na mesma construção textual, o documento aponta os impactos de tais relações comerciais para as tarifas alfandegárias e o consequente aumento do contrato dos dízimos com o "aumento das lavouras". Aquilo que os historiadores buscam separar em mercado interno e mercado externo estava interligado em redes que possibilitavam acumulações de riquezas em diferentes níveis, nos diversos pontos de um "sistema".

A demasiada preocupação da parte da produção histórica com as formas de reprodução econômica no interior da América Portuguesa e a consequente formação de elites coloniais levou à miopia em relação às articulações do mercado interno com dinâmicas econômicas mais gerais. Guillermo Palacios observou que na produção histórica brasileira, “a imagem tradicional do mercado 'interno' como mercado 'interior' continua inquebrantável”, apesar, como aponta o autor, "da flagrante obviedade" da constituição da América Portuguesa "como partes

(21) Abaixo-assinado dos comerciantes das minas do Cuiabá ao rei D. João V. Vila Real do Senhor Bom Jesus do Cuiabá, 20-09-1740; mss., microfilme Rolo 03, doc. 140 (AHU) - NDIHR/UFMT. 
integrantes e sistematicamente articuladas de um império" 22 . Por mais "locais" que possam parecer os movimentos da economia, percebemos que, como afirma Arruda (2000),

a compreensão global desse processo histórico particular envolve a captação dessa interação dialética entre a condição colonial articulada a metrópole, interação esta que o comando se encontra fora do espaço colonial, pois a reprodução das relações sociais não se realiza endogenamente (p. 170).

É importante salientar que mesmo se tratando de um "projeto", a proposta dos comerciantes insere-se em uma lógica de funcionamento das atividades econômicas e de seus efeitos. Nosso intuito não é demonstrar que os comerciantes estariam corretos na previsão sobre os efeitos de um projeto que sequer foi concretizado, mas sim evidenciar que este projeto estava embasado em uma lógica de reprodução de atividades econômicas que orientava, em diferentes níveis, comerciantes, roceiros, fazendeiros, senhores de engenho, autoridades metropolitanas, etc. Raciocínio que é válido não apenas em termos gerais, mas também especificamente tratando-se da fronteira entre a América Portuguesa e a América Espanhola.

Os autores do projeto propunham a construção de feitorias no rio Paraguai, relacionando-o com experiências no extremo sul da América Portuguesa. Em Portugal, no ano de 1713, foi publicada a "Descrição Corográfica e Bélica da Colônia de Sacramento", de autoria do ex-governador da Colônia do Sacramento, Sebastião da Veiga $\mathrm{Cabral}^{23}$, documento que possui similitudes reveladoras em relação ao abaixo-assinado dos comerciantes de Cuiabá. Segundo o historiador Fabrício Prado, além da obra de Veiga Cabral também o "Informe" de Francisco Ribeiro (enviado ao Conselho Ultramarino sob as recomendações de Sebastião da Veiga Cabral) compunha um conjunto de diretrizes para a administração de Sacramento. Segundo Prado (2002),

o conteúdo de tais obras, além de exaltar os recursos naturais da região quanto ao clima e à riqueza de bovinos, mencionava a importância dos mercados ao quais se podia ter acesso pela região. Além do já conhecido mercado portenho e da prata que por aí escoava, sublinhava-se a importância das Missões jesuíticas, do mercado de erva mate e da possibilidade, em caso de ocupação efetiva, de avançar por rotas terrestres até o Alto-Peru, permitindo assim o comércio direto para a obtenção de prata. Alertava ainda para as possibilidades, não apenas de exploração de bovinos (couro e gado em pé) e das cavalhadas (para serem conduzidas às Minas), mas igualmente para a produção de gêneros agrícolas, como trigo e até mesmo linhocânhamo. Justificava todos esses projetos prevendo "grande utilidade q' a Real Fazenda tirará daquelas terras com contracto dos couros e dízimo dos frutos cultivados (p.44).

(22) Cf. Palacios (2004, p. 58).

(23 Cf. Cabral ([1713] 2002, p. 44). 
Poderiam os comerciantes ou o ouvidor de Cuiabá ter lido a "Descrição..." de Veiga Cabral? Principalmente no caso do ouvidor, é provável. Mas mesmo que não, o que parece mais evidente é que entre comerciantes, ouvidor, Conselho Ultramarino houvesse o interesse em desenvolver o comércio via centro da América do Sul com os castelhanos, e já havia um conjunto de enunciados que justificava esse interesse. A diferença espacial, contudo, não poderia ser ignorada. Os comerciantes de Cuiabá queriam provar que era mais conveniente realizar o comércio com os espanhóis pelo centro do que pelo extremo sul do subcontinente americano,

caso tenha efeito este projeto é impar que arraia com vizinhos tão inconstantes como a experiência tem mostrado com os sucessos de nova colônia de Sacramento (...). (...) entrada aos navios que vierem das Índias Ocidentais, rio da Prata, Buenos Aires com prata, couro, e outras fazendas que não sejam da Europa e Índia Oriental, que possam comerciar livremente, levando em troca escravos e outros gentios deste Estado; e que quando se não abrisse o dito comércio por parte dos castelhanos (...) os ditos governadores todo o cuidado e diligência para se abrir por via dos portugueses pelos meios convenientes, que pudesse ser, e que lhe reputaria por particular serviço; e na conformidade dos ditos regimentos se tem abrir o comércio com os castelhanos pela nova Colônia de Sacramento, Rio Grande de São Pedro e por esta capitania de São Paulo, sendo o governador dela Antonio da Silva Caldeira Pimentel.

A importância estratégica da conquista de Sacramento, desde a sua fundação em 1680, era vista pelo Conselho Ultramarino como "um modo de 'colocar prata nesse reino' e que a existência da Colônia impulsionara o desvio do metal desde as minas potosinas até o Brasil" ${ }^{24}$. Segundo Fabrício Prado (2002),

Além da prata e do couro, outro atrativo importante da região platina no período eram os mercados de Buenos Aires, Paraguai e do Alto-Peru. Essas regiões eram marginalizadas no abastecimento oficial hispânico. A baixa frequência de embarcações oficiais autorizadas a comerciar artigos manufaturados fazia com que tais regiões encontrassem alternativas para o abastecimento. $\mathrm{O}$ contrabando surgia como uma opção frente as carências do sistema oficial e constituía uma atividade rotineira e muito lucrativa no Prata (p. 76).

A Coroa espanhola por seu lado também percebia a evasão de prata via contrabando, e tentou ao longo de todo o século XVIII recuperar a Colônia de Sacramento, o que só conseguiu de forma definitiva com o Tratado de Santo Ildelfonso em 1777. Durante todo o período referente à nossa pesquisa, a primeira metade do século XVIII, a Colônia de Sacramento foi objeto de disputa, ora mais ora menos tensa, entre as coroas ibéricas.

A partir de 1737, contudo, devido a tensões locais entre súditos portugueses e espanhóis e também a questões geopolíticas de ambas as coroas,

(24) Cf. Ameghino, Azcuy e Birocco (1998, p. 34). 
nota-se a "inflexão da estratégia lusitana". De um ambiente urbano com produção agropastoril em seu entorno, Sacramento "a partir de então, assumia a constituição de um porto comercial sem um entorno agrícola e uma possível moeda de troca por territórios de Espanha" (Prado, 2002, p. 53).

É impossível não articular as ações em torno de Sacramento com o "projeto" dos comerciantes. Parece bastante legítimo defendermos a hipótese de que estabelecer os territórios do centro da América do Sul e abrir mão de Sacramento fez parte de uma estratégia de abastecer, por uma via mais rápida e conveniente, mercados andinos e consequentemente obter riquezas produzidas no lado hispânico, projeto que se concretizaria, não controlado por "homens de negócio", mas monopolizado pela coroa através da fundação da Companhia de Comércio do Grão Pará e Maranhão, já na segunda metade do século XVIII, em 1755 .

Ainda em relação ao abaixo-assinado dos comerciantes, estes afirmam que "aumentando-se a povoação necessariamente se hão de aplicar alguns moradores a tratar de lavoura, outros a comerciar conforme a inclinação e possibilidade de cada um (...)". Além da lavoura e do comércio, os suplicantes também apontam "que é certo que estas campanhas tão dilatadas e em todas elas há ouro, e razão para que se não extrai é por não haver quem o procure e tire" 25 . Comércio, lavoura e mineração, três atividades que contavam com uma diversidade de agentes sociais para sua execução, não sendo, portanto, apenas a "possibilidade" financeira que determinava a prática de uma ou outra atividade, mas também a "inclinação". O interesse pelo ouro era indubitavelmente presente. Os senhores de engenho, proprietários de grandes "currais", comerciantes e mineradores, desenvolviam, contudo, diferentes estratégias para obtê-lo. O alto preço das mercadorias, sobretudo dos escravos, ferramentas, sal, pólvora são indícios de que boa parte do ouro que circulava nas minas do Cuiabá e do Mato Grosso passava pelas mãos dos negociantes. Os negociantes previam de forma detalhada como funcionariam as feitorias, apontando valores percentuais para os comerciantes que fizessem uso destas, assim como do aparato necessário para sua defesa.

Concomitantemente ao projeto de desenvolver o comércio com as grandes praças comerciais hispano-americanas, os comerciantes também buscavam desenvolver relações comerciais com as missões jesuíticas, principalmente ao longo do rio Guaporé. O primeiro contato de que se tem notícia entre portugueses e essas missões ocorreu em 1740, por meio de uma "bandeirinha", "uma expedição exploratória, visando ao levantamento da região para abrir opções nas rotas de troca e espionar as aldeias jesuíticas" e "que custou meia arroba de ouro,

(25) Abaixo-assinado dos comerciantes das minas do Cuiabá ao rei D. João V. Vila Real do Senhor Bom Jesus do Cuiabá, 20-09-1740; mss., microfilme Rolo 03, doc. 140 (AHU) - NDIHR/UFMT. 
foi bem recebida em São Rafael e retornou a Cuiabá em novembro de 1740" (Canavarros, 2004, p. 216). Outra viagem exploratória para o território espanhol ocorreu em 1742, e partiu do Arraial de São Francisco Xavier. Essa viagem foi minuciosamente relatada em uma "relação" feita pelo ouvidor geral da câmara de Cuiabá, João Gonçalves Pereira (Pereira, 2001). Através desse documento percebemos como as atividades produtivas articulavam-se à expansão das conquistas portuguesas.

A pescaria no rio Guaporé e a venda do peixe salgado nos arraiais de Mato Grosso foram atividades presentes desde os primeiros anos de colonização da região e reproduziram-se, assim como em Cuiabá, por uma rede que articulava livres pobres (inclusive índios) que se dedicavam à pescaria e pessoas que vendiam os peixes nos arraiais e povoados. Os livres pobres avançavam a fronteira e formavam ambientes coloniais como o "Porto da Pescaria", que se transformavam em locais estratégicos para o contato entre portugueses e espanhóis. Além da pescaria, a produção de alimentos também foi fundamental para a transformação do "Porto da Pescaria" em paragem estratégica e povoação fixa:

chegado ao rio Guaporé em sítio chamado da Pescaria, fabricaram mais algumas canoas e com toda cautela e vigilância se prepararam de mantimentos e mais necessário para a viagem (...) Preparados todos os sobreditos, seguiram viagem pelo rio Guaporé abaixo no dia 13 de junho do ano passado, levando em sua companhia João dos Santos Verneque, pescador, (...) (Pereira, 2001, p. 11-12).

Além de visitar as missões jesuíticas, esses sertanistas foram os primeiros, que se tem notícia, que empreenderam viagem de Mato Grosso ao Pará a partir do rio Guaporé (Anais da Vila Bela, 2001). Temos indícios de que a partir desse primeiro contato rapidamente desenvolveram-se atividades de contrabando. Logo em 1743, houve denúncias de que açúcar, sabão, pano de algodão e aguardente eram contrabandeados por comerciantes ${ }^{26}$.

Os comerciantes que ambicionavam desenvolver comércio com os espanhóis negociavam escravos africanos, aguardente, tabaco, gêneros alimentícios, vestimentas, e "fazendas" de uma forma geral, em Cuiabá e em Mato Grosso. Caso as relações de comércio ambicionadas pelos comerciantes de Cuiabá tivessem o êxito esperado, a intensificação do comércio de escravos africanos teria implicação sobre os portos do Atlântico e, portanto, sobre a alfândega; a produção e venda de tabaco e aguardente, se contasse com a produção paulista e fluminense, teria efeito sobre o "direito das entradas". A venda da produção agrícola e dos derivados das lavouras das minas do Cuiabá e do Mato Grosso aumentaria a arrecadação dos dízimos e aumentaria o valor dos contratos administrados pela

(26) Carta do provedor Manoel Rodrigues Torres ao rei; Lisboa; 01-04-1743, microficha 39 doc. 326 (AHU) - NDHIR/UFMT. 
câmara, como o corte de carne, o comércio de aguardente, etc. Ainda, em relação a todas as mercadorias que fossem levadas às feitorias, deveriam ser pagos dez por cento do valor destas para a manutenção das mesmas ${ }^{27}$. No entanto, apesar de corresponder a formas de exploração do trabalho e a cadeias produtivas diversas, todas essas mercadorias, indistintamente, serviriam para obter "prata, couro, e outras fazendas" dos espanhóis.

As mercadorias, quando adquiriam uma forma-valor, tinham silenciadas as relações que tornaram possíveis sua produção, seja em transações locais ou atlânticas, e que possibilitavam acumulações de capital em diferentes escalas. Não havendo, portanto, duas lógicas distintas de acumulação de capital, uma interna, outra externa, mas um "sistema" que articulava a produção voltada para o mercado interno e para o mercado externo, o que pode ser demonstrado tanto pela análise das relações comerciais quanto na lucrativa arrematação dos contratos régios.

Uma análise sobre as relações comerciais mostra que os mesmos comerciantes que comercializavam nas minas do Cuiabá e do Mato Grosso, sal, escravos africanos, roupas vindas da Europa e das Índias Orientais, comercializavam também mercadorias produzidas localmente. Por sua vez todo o capital reproduzido com essas atividades comerciais servia para "abastecer" o "sistema" como um todo, desde o responsável em aprisionar escravos na África até os roceiros que vendiam alimentos ao longo dos caminhos, passando pelos grandes comerciantes do Rio de Janeiro e de Lisboa. No caso dos contratos régios, essa relação fica ainda mais evidente já que todas as mercadorias pagavam direitos de entradas aos caminhos que levavam às minas, assim como toda a produção, fosse ela produzida por mão de obra escrava ou de livres pobres, deveria pagar os dízimos. A Coroa e o arrematador do contrato retiravam seus lucros da exploração de todas essas atividades em conjunto.

Sobre a articulação das atividades comerciais no centro da América do Sul ao Império Português, o ouvidor que apoia o projeto dos comerciantes argumenta que "parece novo o requerimento dos suplicantes, mas é tão antigo como são as feitorias da Ásia, da Costa da África..."28. Além de relacionar o projeto com outros domínios portugueses, os colonos luso-americanos o relacionam à conjuntura dos outros grandes impérios coloniais europeus,

por ficar sendo aos castelhanos o trato que a eles oferece por estes arraiais com mais comodidade da distância, do que pela Colônia (Sacramento) com os portugueses; e pela contra costa do mar [...] com os franceses, holandeses

(27) Abaixo-assinado dos comerciantes das minas do Cuiabá ao rei D. João V. Vila Real do Senhor Bom Jesus do Cuiabá, 20-09-1740; mss., microfilme Rolo 03, doc. 140 (AHU) - NDIHR/UFMT.

(28) Carta do ouvidor João Gonçalves Pereira ao rei D. João V. Vila Real do Senhor Bom Jesus do Cuiabá, 20-09-1740; mss., microfilme Rolo 03, doc. 140 (AHU) - NDIHR/UFMT. 
e ingleses, e havendo guerras [...] os socorros dos (castelhanos) será o dito comércio $^{29}$.

Uma percepção relativamente clara da dinâmica econômica que envolvia o comércio Atlântico e Pacífico, por parte dos comerciantes, é reveladora de como numa região em que esses oceanos eram quase equidistantes pensavam-se e desenvolviam-se atividades econômicas tendo como parâmetros a dinâmica do Império Português, do qual fazia parte, como colônia, no limite de sua fronteira, e o Império Hispânico, com o qual rivalizavam territórios litigiosos e estabeleciam direta ou indiretamente uma série de contatos. Nosso objetivo não é demonstrar que os comerciantes eram "vassalos leais" ou que tinham uma "identidade" portuguesa, o que não está em questão. Procuramos demonstrar que estes articulavam seus interesses aos do Império Português, do qual se sentiam parte e tinham certa percepção de seu funcionamento. No entanto, além do império havia a percepção não tão clara, mas evidente, do funcionamento de uma economia mundial que articulava o interesse dos comerciantes de Cuiabá com outros impérios emergentes, como o francês, o inglês e o holandês.

Foi com muita cautela que a Coroa avaliou o desenvolvimento de relações comerciais com os espanhóis. Em carta enviada, em 1746, à Vila Real, foram citados os pareceres do governador de São Paulo, do governador do Rio de Janeiro, do procurador da Fazenda Real e do procurador da Coroa. Apesar dos pareceres diferenciados, nenhum deles apoiou a proposta dos comerciantes, prevalecendo uma política de defesa com a proposta da construção de fortalezas e não de feitorias ${ }^{30}$. A consulta do Conselho Ultramarino acatada pelo rei não apenas fazia referência às feitorias,

as bandeirinhas sertanejas e abertura de picadas ou caminhos novos serviam de alguma utilidade particular, mas de prejuízo e ruína do público, porque muitos morriam nas mãos dos bárbaros, e se fazia notório aos castelhanos a vizinhança de nossas terras, ou do nosso ouro e diamantes, o que se fazia muito perigoso, tendo aquela nação mais poder, e sendo mais numerosa que a nossa; e que assim parecia se devia repetir a ordem que próba abrir caminhos novos principalmente para a parte que confina com os castelhanos e o comerciar com estes ${ }^{31}$.

No mesmo documento, o conselho sugere que ministros envolvidos nesse comércio deveriam perder seus cargos e os comerciantes "que por si, ou por outrem, fizerem aquelas negociações" teriam "confiscados os bens". Via-se frustrada a intenção dos luso-americanos em introduzir, pelo menos legalmente,

(29) Carta do ouvidor João Gonçalves Pereira ao rei D. João V. Vila Real do Senhor Bom Jesus do Cuiabá, 20-09-1740; mss., microfilme Rolo 03, doc. 140 (AHU) - NDIHR/UFMT.

(30) Consulta do Conselho Ultramarino ao rei D. João V. Lisboa, 26-04-1746; mss., microfilme Rolo 03 , doc. 196 (AHU) - NDIHR/UFMT.

(31) Consulta do Conselho Ultramarino ao rei D. João V. Lisboa, 26-04-1746; mss., microfilme Rolo 03 , doc. 196 (AHU) - NDIHR/UFMT. 
suas mercadorias, via centro da América do Sul ao "opulentíssimo reino do Peru". Entretanto, o longo documento que analisamos deixa bastante evidentes os laços que ligavam as atividades econômicas no centro da América do Sul a múltiplas espacialidades, rejeitando qualquer tese que confira a característica de isolamento às atividades produtivas e comerciais desenvolvidas no termo da Vila Real do Senhor Bom Jesus do Cuiabá, seja em relação às praças comerciais da América Portuguesa, em relação ao Império Português, ou ainda à economia-mundo, à qual estava vinculada através de práticas típicas da Época Moderna e inserida no processo de Acumulação Primitiva do Capital.

\section{Conclusões}

O leitor pôde perceber que não optamos por inserir a rica documentação que analisamos neste texto em um aparato teórico rígido e consistente, encaixando os documentos em um "sentido" já existente na teoria. Procuramos o contrário, problematizar os aparatos teóricos a partir dos documentos que analisamos a fim de reagrupá-los de modo que parte da complexidade da documentação fosse contemplada e que fossem abertas possibilidades de interpretação que escapassem da rigidez dos modelos explicativos.

Do aparato teórico marxista, utilizamo-nos do conceito de fetiche da mercadoria para abordarmos o "mistério" que envolvia o ouro que das minas de Cuiabá e de Mato Grosso era enviado para Portugal. Mostramos como nesse ouro estava contido o trabalho de muitos que não estavam diretamente ligados às atividades auríferas. Para vincularmos essas atividades a processos sociais mais amplos, optamos por coadunar duas concepções que a nosso ver são antes complementares que contraditórias: a acumulação primitiva do capital (Marx) e a economia-mundo (Braudel), visto que percebemos, junto com o próprio Marx, que a "circulação de mercadorias é o ponto de partida do capital. Produção de mercadorias e circulação desenvolvida de mercadorias, comércio, são os pressupostos históricos sob os quais ele surge. Comércio mundial e mercado mundial inauguram no século XVI a moderna história da vida do capital" (Marx, 1996, p. 267).

Com Braudel, contudo, mais do que com Marx, é possível perceber a materialização desta economia, os circuitos mercantis, a espacialização das relações econômicas. Diferentemente de autores como Maurice Dobb (que possuem uma leitura mais esquemática de Marx sobre a reprodução econômica na época da acumulação primitiva, tendo como referência o período posterior, reduzindo as relações econômicas dos séculos XVI a XVIII apenas como uma fase transitória entre o feudalismo e o capitalismo), com Braudel podemos vislumbrar a "natureza" do capital mercantil e seu significado para os agentes históricos contemporâneos. 
Mesmo com todas as ressalvas que fizemos ao longo do artigo, defendemos que é fundamental para compreender a vinculação entre práticas econômicas reproduzidas no centro da América do Sul e a economia-mundo europeia, a noção de "sistema colonial", sem a qual é impossível perceber as mediações entre a produção aurífera e a acumulação primitiva de capital por meio do comércio mundial.

As atividades produtivas, portanto, reproduzidas no centro da América do Sul não estavam isoladas e/ou restritas ao âmbito local. Primeiramente apenas o comércio monçoeiro interligava a produção local à produção de regiões mais próximas ao litoral atlântico. A abertura do caminho de terra de Goiás à Vila Real do Senhor Bom Jesus do Cuiabá (1737), outro caminho da Vila Real até os arraiais de Mato Grosso e o contato com territórios espanhóis completaram uma linha tortuosa que unia o centro da América do Sul aos oceanos Atlântico e Pacífico. Portanto, a produção de Cuiabá e de Mato Grosso estava ligada a circuitos mercantis locais, regionais, coloniais, em relações comerciais do estado do Brasil com o estado do Grão-Pará e Maranhão e ainda com os territórios espanhóis. A análise da produção de mercadorias no meio rural, a percepção dos caminhos que a mercadoria percorria e de como o valor era transmutado em reprodução e acumulação de capitais permitiram-nos construir uma análise sobre as articulações entre mercado interno, sistema colonial e a reprodução de uma economia-mundo europeia. Ao mesmo tempo em que permitia a formação de elites locais, a produção e o comércio interno, também possuía mecanismos de extroversão de capitais, seja por meio da cobrança de tributos, como pelo comércio. Nos dois casos, contudo, com a mediação do "sistema colonial".

A utilização da noção de "fetichismo da mercadoria", de Marx, pode ter soado como um atraso, um retorno, em um momento de renovação epistemológica no discurso histórico. No entanto, parece-nos que essa noção tem convergências com as reflexões contemporâneas. Pretendemos mostrar que a análise do "caráter misterioso" da mercadoria-ouro pode contribuir para os estudos dos valores, não apenas como índices monetários, mas também como indícios ${ }^{32}$ de relações econômicas e sociais que permanecem como hieróglifos sociais à espera de desvendamento.

\section{Bibliografia}

AMEGHINO, Eduardo Azcuy; BIROCCO, Carlos María. As colônias do Rio da Prata e o Brasil: geopolítica, poder, economia e sociedade. In: CERVO, Amado Luiz; Rapoport, Mario (Org.). História do Cone Sul. Brasília: Editora Universidade de Brasília, 1998, p. 34 .

(32) Sobre o "paradigma indiciário", ver Ginzburg (1989). 
ANAIS da Vila Bela da Santíssima Trindade. IHGMT. Publicações Avulsas, n. 28, 2001.

ARRUDA, José Jobson de A. O Brasil no comércio colonial. São Paulo: Editora Ática, 1980.

- O sentido da Colônia. Revisitando a crise do Antigo Sistema Colonial no Brasil (1780-1830). In: TENGARRINHA, José (Org.). História de Portugal. Bauru-SP: Edusc; São Paulo-SP: Unesp; Portugal-PO: Instituto Camões, 2000.

BRAUDEL, Fernand. Civilização material, economia e capitalismo século XV-XVIII. V. II - O jogo das trocas. São Paulo: Martins Fontes, 2005.

. Civilização material, economia e capitalismo século XV-XVIII. V. I - As estruturas do cotidiano. São Paulo: Martins Fontes, 2005.

CABRAL, Sebastião da Veiga. Descrição corográfica e Coleção Histórica do Continente da Nova Colônia de Sacramento [1713]". RIHGU. T. XXIV. Montevidéu: Imprenta Nacional, 1965 apud PRADO, Fabrício. Colônia de sacramento: o extremo sul da América portuguesa no século XVIII. Porto Alegre: F. P. Prado, 2002. p. 44.

CANAVARROS, Otávio. O poder metropolitano em Cuiabá (1727-1752). Cuiabá: EdUMFT, 2004.

FLORENTINO, Manolo; FRAGOSO, João. O arcaísmo como projeto: mercado atlântico, sociedade agrária e elite mercantil em uma economia colonial tardia: Rio de Janeiro, c. 1790- c. 1840. Rio de Janeiro: Civilização Brasileira, 2001.

FRAGOSO, João. A formação de economia colonial no Rio de Janeiro e de sua primeira elite senhorial (séc. XVI e XVII). In: FRAGOSO, João; BICALHO, Maria F.; GOUVÊA, Maria de F. (Org.). O antigo regime nos trópicos: a dinâmica imperial portuguesa (séculos XVI e XVII). Rio de Janeiro: Civilização Brasileira, 2001. p. 29-73.

FRAGOSO, João Luís Ribeiro. Homens de grossa aventura: acumulação e hierarquia na praça mercantil do Rio de Janeiro (1790-1830). Rio de Janeiro: Civilização Brasileira, 1998.

FURTADO, Celso. Formação econômica do Brasil. 32. ed. São Paulo: Companhia Editora Nacional, 2003.

GODINHO, Vitorino Magalhães. Portugal, as frotas do açúcar e as frotas do ouro (16701770). Revista de História, São Paulo, n. 15, 1950.

GINZBURG, Carlo. Mitos, emblemas, sinais: morfologia e história. São Paulo: Cia. das Letras, 1989.

LUIS, Washington. Capitania de São Paulo - Governo de Rodrigo César de Meneses. 2. ed. São Paulo: Cia. Ed. Nacional, 1938.

MARX, Karl. O capital. Livro I. Rio de Janeiro: Difel, 1985. . O Capital. Livro I. São Paulo: Círculo do Livro, 1996. ; ENGELS, Friedrich. A ideologia alemã. São Paulo: Editora Moraes, 1984. 
NOVAIS, Fernando A. Condições de privacidade na Colônia. In: NOVAIS, Fernando A. (Org.). História da vida privada no Brasil. São Paulo: Cia. das Letras, 1997. v. 1, p. 1339.

. Portugal e Brasil na crise do Antigo Sistema Colonial (1777-1808). São Paulo: Hucitec, 1986.

- O Brasil nos quadros do Antigo Sistema Colonial. In: MOTA, Carlos Guilherme. Brasil em perspectiva. São Paulo: Difel, 1981.

OSÓRIO, Helen. As elites econômicas e a arrematação de contratos: o exemplo do Rio Grande do Sul. In: FRAGOSO, João; BICALHO, Maria F.; GOUVÊA, Maria de F. (Org.). $O$ antigo regime nos trópicos: a dinâmica imperial portuguesa (séculos XVI e XVII). Rio de Janeiro: Civilização Brasileira, 2001.

PALACIOS, Guillermo. Campesinato e escravidão no Brasil. Agricultores livres e pobres na Capitania Geral de Pernambuco (1700-1817). Brasília: Ed. UnB, 2004.

PEREIRA, Gonçalves Pereira. Informações sobre as primeiras expedições Guaporé abaixo e as missões jesuiticas de Moxos. Cuiabá: IHGMT, 2001.

PINTO, Virgílio Noya. O ouro brasileiro e o comércio anglo-português. São Paulo: Cia. Editora Nacional, 1979.

PRADO, Fabrício. Colônia de sacramento: o extremo sul da América portuguesa no século XVIII. Porto Alegre: F. P. Prado, 2002.

PRADO JÚNIOR, Caio. Formação do Brasil Contemporâneo - Colônia. São Paulo: Brasiliense, 1997.

ROSA, Carlos Alberto. O comércio da conquista. Rev. Universidade, Cuiabá, Ano II, n. 1, jan./abril 1982.

O urbano colonial na terra da conquista. In: ROSA, Carlos Alberto; JESUS, Nauk Maria (Org.). A terra da conquista: a história de Mato Grosso colonial. Cuiabá: Ed. Adriana, 2003.

SÁ, José Barboza de. Relação das povoações do Cuiabá e Mato Groso de seus princípios até os presentes tempos. Cuiabá: Ed. UFMT/Secretaria de Educação e Cultura, 1975.

SAMPAIO, Antonio Carlos Jucá de. O agro fluminense na curva do tempo: 1650-1750. Estudos de História, Franca, v. 8, n. 2, 2001.

. Os homens de negócio do Rio de Janeiro e sua atuação nos quadros do Império Português (1701-1750). In: FRAGOSO, João; BICALHO, Maria F.; GOUVÊA, Maria de F. (Org.). O antigo regime nos trópicos: a dinâmica imperial portuguesa (séculos XVI e XVII). Rio de Janeiro: Civilização Brasileira, 2001.

SANTOS, Milton. Metamorfoses do espaço habitado: fundamentos teórico e metodológico da geografia. São Paulo: Hucitec, 1988.

SCHWARTZ, Stuart. Escravos, roceiros e rebeldes. Bauru: Edusc, 2001. 
Tiago Kramer de Oliveira

SCHWARTZ, Stuart. Mentalidades e estruturas sociais no Brasil colonial: uma resenha coletiva. Economia e Sociedade, Campinas, n. 13, p. 129-153, dez. 1999.

SIMONSEN, Roberto. História econômica do Brasil (1500-1820). São Paulo: Cia. Editora Nacional, 1978.

VILAR, Pierre. Ouro e moeda na história (1450-1920). Rio de Janeiro: Paz e Terra, 1980. 